\title{
INVESTIGATION OF CONTRAST RATIO DEPENDENCE ON THE ANGULAR DEVIATION OF THE LASER BEAM DIRECTION FROM THE OPTICAL AXIS OF POCKELS CELLS BASED ON THE BETA BARIUM BORATE CRYSTAL
}

\author{
G. Sinkevičius ${ }^{a, b}$ and A. Baškys ${ }^{a, b}$ \\ ${ }^{a}$ Department of Material Science and Electrical Engineering, Center for Physical Sciences and Technology, Sauletekio 3, \\ 10257 Vilnius, Lithuania \\ ${ }^{\mathrm{b}}$ Faculty of Electronics, Vilnius Gediminas Technical University, Naugarduko 41, 03227 Vilnius, Lithuania \\ Email: giedrius.sinkevicius@ftmc.lt
}

Received 31 January 2019; revised 27 March 2019; accepted 21 June 2019

\begin{abstract}
Dependences of the contrast ratio on the angular deviation of the optical axis with a step of 2 arcmin 28 arcsec have been obtained for Pockels cells based on beta barium borate crystals in the $49 \operatorname{arcmin} 34 \operatorname{arcsec}$ range. The investigation was conducted for a single Pockels cell and for a double cell based on optically aligned crystals. The results of investigations can be applied for the calculation of the laser beam focus in order to use a high contrast ratio in high-power laser systems when the light is modulated using Q-switching.
\end{abstract}

Keywords: optical properties, electro-optical effects, Q-switching, laser radiation characteristics, optical transmission coefficients, nonlinear optical crystals

PACS: 78.20.Jq, 42.60.Gd, 42.60.Jf, 78.20.Ci, 42.70.Mp

\section{Introduction}

High-peak-power and ultrashort-pulse lasers with the external modulation of beam intensity are extensively used in the modern industry, e.g. in the micromachining of bulk glass [1]. The repetition rate and the number of pulses have to be varied depending on the micromachined material. Such laser modulation is achieved via Q-switching technique [2]. The key element for such a task is an electro-optic modulator, also known as a Pockels cell, which acts as a voltage-controlled wave plate. The working principle is based on the Pockels effect: a linear change of the crystal birefringence produced via an applied external electric field.

The most common materials used for the realisation of Pockels cells are beta barium borate (BBO), potassium titanyl phosphate (KTP) and potassium dideuterium phosphate (DKDP) crys- tals [3]. The Pockels cells based on the BBO crystal have been investigated in this work. They are most popular in the femtosecond high-average-power laser systems. The advantages of the $\mathrm{BBO}$ crystal over the DKDP and KTP crystals are a lower piezoelectric ringing phenomenon [4-7] and a lower sensitivity of the electro-optic coefficient to temperature changes [8-10]. The birefringence inside the $\mathrm{BBO}$ crystal is introduced by the electric field, which is created using high-voltage pulses applied to the electrodes that are fitted on two sides of the crystal. When the electric field is applied, the transverse linear Pockels effect is achieved [11].

The contrast ratio is one of the main parameters of the Pockels cell [12]. It is expressed as the ratio of the $s$ and p polarisation beams intensity on the output of the Pockels cell crystal [13]. The contrast ratio decreases when the depolarisation of the light inside the Pockels cell crystal increases. Practically, 
the Pockels cell crystal has two contrast ratios: with no external electrical field (ICR) and with the external electrical field applied (VCR) to the crystal. In order to achieve a high contrast ratio value of the Pockels cell crystal, the crystal has to be aligned with precision inside the laser system.

In most cases the collimated laser beam is used when the light is modulated in the Q-switching regime, however, the collimation is not possible in some cases in high-peak-power laser systems [14, 15]. Therefore, beam components in such situations travel through the crystal at different angles and, as a consequence, the contrast ratio of the Pockels cell crystal decreases. The only recommendation that the optical axis of the Pockels cell has to be parallel to the laser beam within 10 arcmin can be found in the literature [8].

The novelty of this work is that the dependences of the contrast ratio on the angular deviation of the optical axis for Pockels cells based on BBO crystals have been obtained in the $49 \operatorname{arcmin} 34 \operatorname{arcsec}$ range with a step of 2 arcmin 28 arcsec. The results of investigations can be applied for the calculation of the laser beam focus in order to use a high contrast ratio in high-power laser systems when the light is modulated using Q-switching.

\section{Experimental setup}

The experimental setup stand includes two parts: the Pockels cell crystal contrast ratio measurement part and the optical axis angular deviation measurement part. The Pockels cell crystal contrast ratio measurement part is shown in Fig. 1. It consists of a diode-pumped solid-state laser (L1), three polariz-

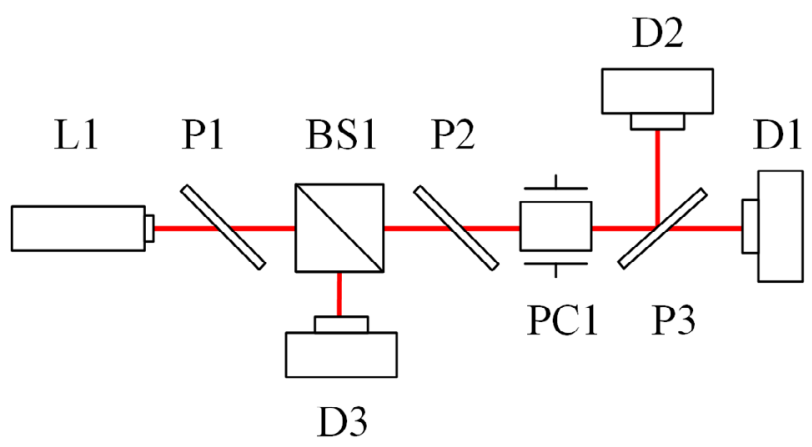

Fig. 1. The experimental setup of Pockels cells contrast ratio measurement. ers (P1, P2, P3), a non-polarising beamsplitter cube (BS1), a Pockels cell (PC1) and three detectors (D1, D2, D3). The laser with $1064 \mathrm{~nm}$ wavelength and $1 \mathrm{~W}$ output power is used. The laser beam with a diameter of $1.5 \mathrm{~mm}$ and a divergence of 2 mrad travels through the first polarizer P1 to the beamsplitter cube BS1, which was selected to have a reflection of around 5\%. The reflection from the beamsplitter cube travels to the detector D3. This detector is used for two purposes: for the stabilization of the contrast ratio in the case of laser output power fluctuations; for the estimation of the maximal beam intensity of the Pockels cell, the value of which is necessary for calculation of the crystal contrast ratio.

The laser beam, after the beamsplitter cube BS1, travels through the second polarizer P2 to the Pockels cell crystal PC1. The beam of the laser is deflected from the third polarizer P3 if the external electrical field is not applied to the Pockels cell crystal and, therefore, the polarisation of the light is not changed. Most of the laser beam intensity reaches the detector D2 in such a case and only a small amount of the laser beam intensity arrives to the detector D1. When the external electrical field is applied to the Pockels cell crystal and, as a consequence, the polarisation of the light is changed, most of the laser beam intensity arrives to the detector D1 and only a small amount of the laser beam intensity arrives to the detector D2.

In order to achieve a high accuracy of the contrast ratio measurement, the output power of the laser L1 has to be increased. However, the detector can saturate at high beam intensity. This problem can be solved using the optical filter with the known value of light transmittance in front of the saturated detector D1 or D2 and by appropriate calibrating of the detector D3. This solution allows us to estimate the beam intensity even when the detector D1 or D2 is saturated. The drawback of such a method is that the calibrated maximal beam intensity estimated by the detector D3 does not take into consideration the light absorption in the Pockels cell. Manufacturers specify that absorption of the Pockels cell is less than $2 \%$.

The optical axis deviation measurement of the Pockels cell crystal was performed while fitting a cell into a holder (Fig. 2). The tilt angle $\alpha$ of the Pockels cell is selected via adjustment screws (Fig. 2). The laser diode was fitted inside the holder and pointed to the surface perpendicular to the laser beam in order to estimate the relation 




Fig. 2. The experimental setup of optical axis angular deviation measurement. 1 and 2 are adjustment screws; (a) is the distance of laser beam displacement on the surface; (b) is the distance between the surface and laser; $\alpha$ is the tilt angle.

between the tilt angle of the holder and the step of the screw. This was accomplished by adjusting of the screw and by measurement of the laser beam displacement on the surface. Knowing the beam displacement and the distance between the surface and the laser, the tilt angle is calculated. The dependence of the contrast ratio of the Pockels cell crystal on the adjustment screw position (on the angular deviation of the optical axis) was measured. The step of the angular deviation measurement was 2 arcmin 28 arcsec in the measurement band of $49 \operatorname{arcmin} 34 \mathrm{arcsec}$.

\section{Analysis of contrast ratio dependence on the angular deviation of the crystal}

Two BBO Pockels cells PCB4S-1064 (EksmaOptics) with crystal dimensions of $4 \times 4 \times 20 \mathrm{~mm}$ were investigated. The concentricity of the optical axis in relation to the housing is less than 30 arcmin. The contrast ratio dependence on the crystal optical axis angular deviation when no external electrical field is applied to the crystal was measured. The obtained results for the first and second investigated crystals are presented in Figs. 3 and 4, respectively. They show that the highest contrast ratio value is obtained at the centre of the optical axis in such a case. The contrast ratio distribution correlates with the optical isogyre pattern of crystals (Fig. 5(a)). The isogyre pattern of a Pockels cell crystal can be seen when the laser light is scattered inside the crystal and the scattered light is polarised.

The analysis of the contrast ratio dependences presented in Figs. 3 and 4 shows that in the case when no external electrical field is applied to the crystal, the contrast ratio will decrease more than two times

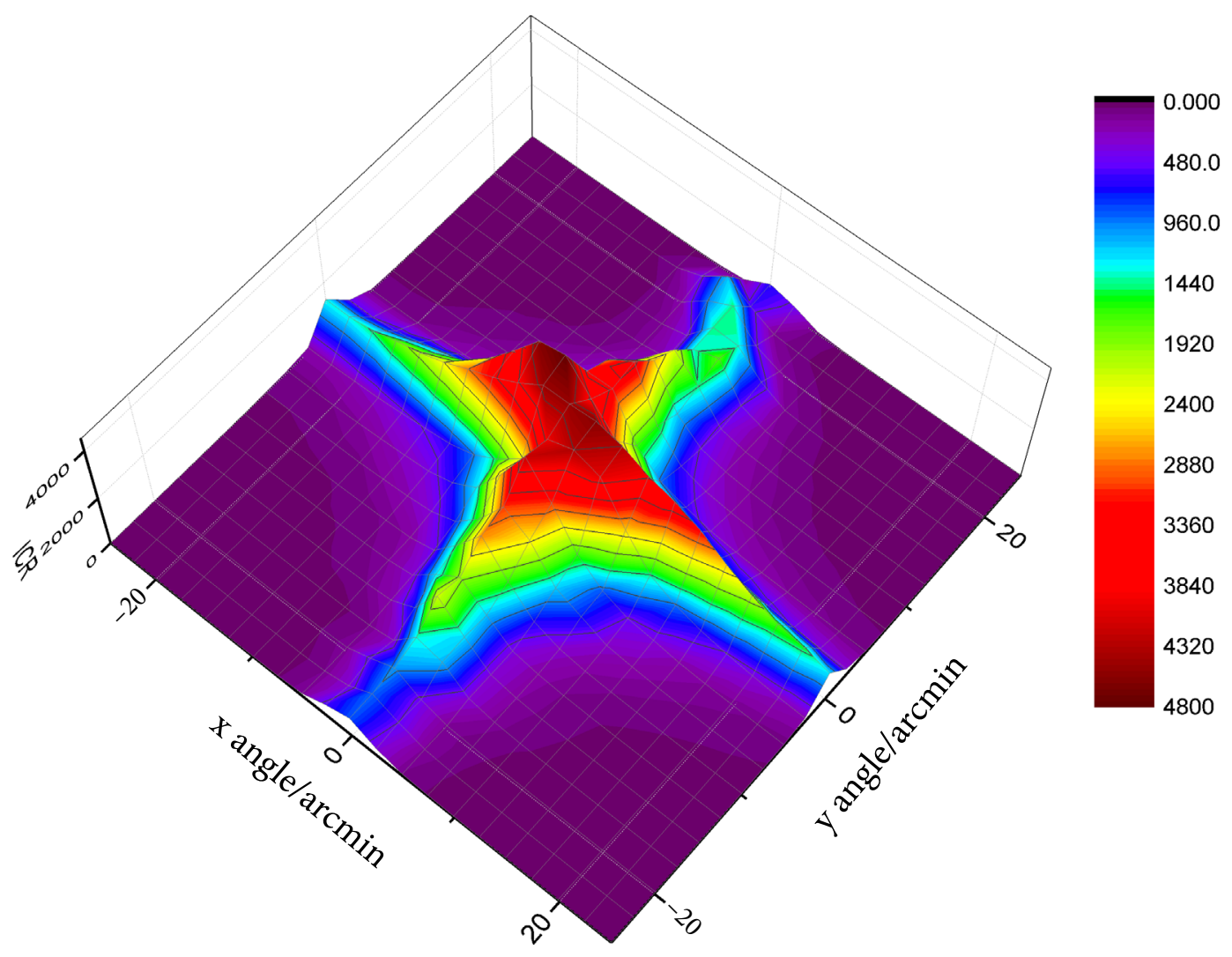

Fig. 3. Contrast ratio dependence on the angular deviation when no external electrical field is applied. Crystal No. 1. 


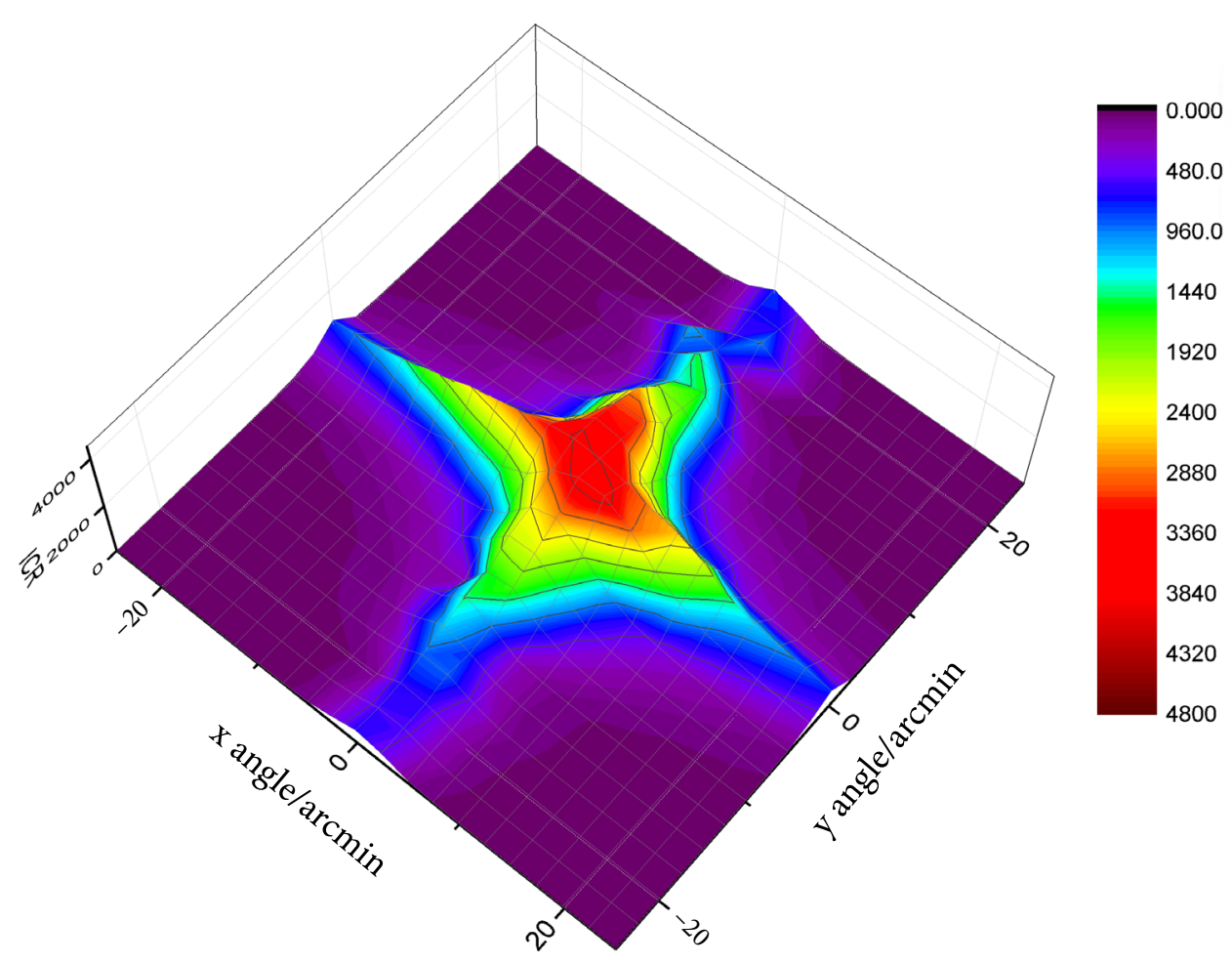

Fig. 4. Contrast ratio dependence on the angular deviation when no external electrical field is applied. Crystal No. 2.

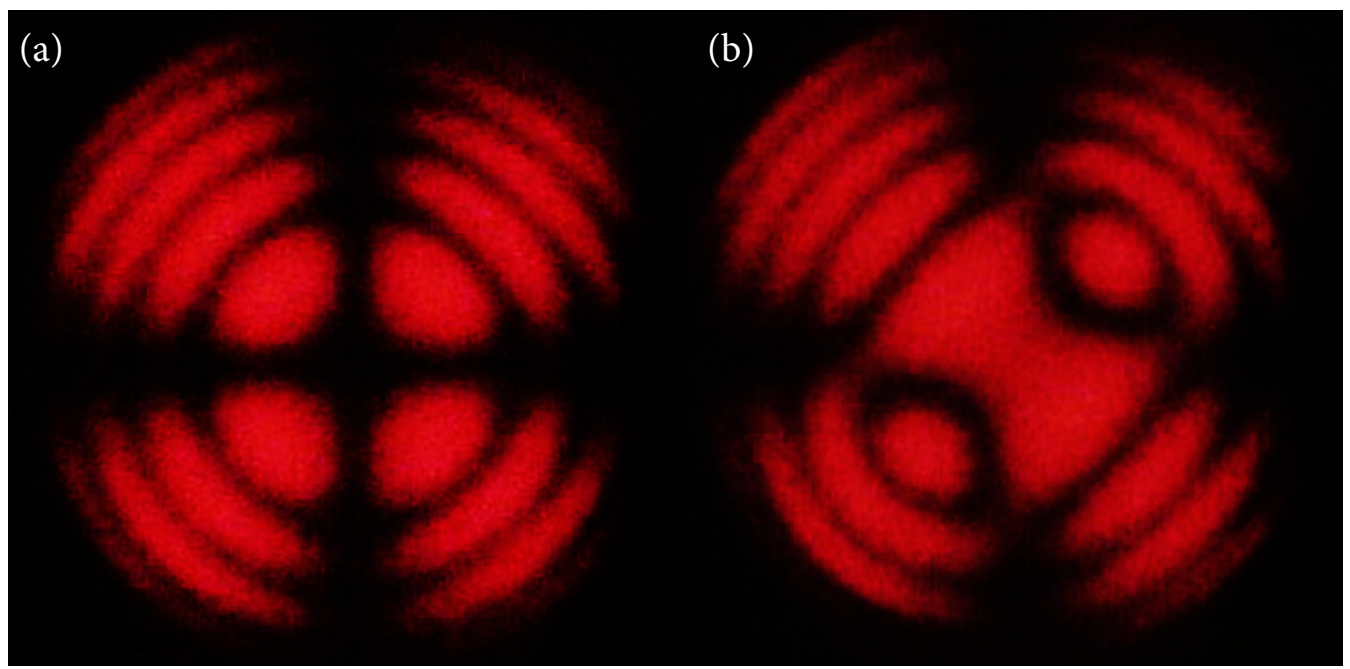

Fig. 5. Isogyre patterns of Pockels cell: when no external electric field is applied (a); when external electric field is applied (b).

if an angular deviation from the centre of the crystal optical axis is more than 5 arcmin.

The results of investigation of the Pockels cell contrast ratio dependence on the crystal optical axis angular deviation when the external electrical field is applied to the cell are given for the first and second investigated crystals in Figs. 6 and 7 , respec- tively. The measurement results show that the contrast ratio has the highest values at the centre of the optical axis. It was unexpected that the distribution of the contrast ratio when the external electrical field was applied did not correlate directly with a form of the isogyre figure (Fig. 5(b)). The contrast ratio in the centre of the optical axis is distributed in 


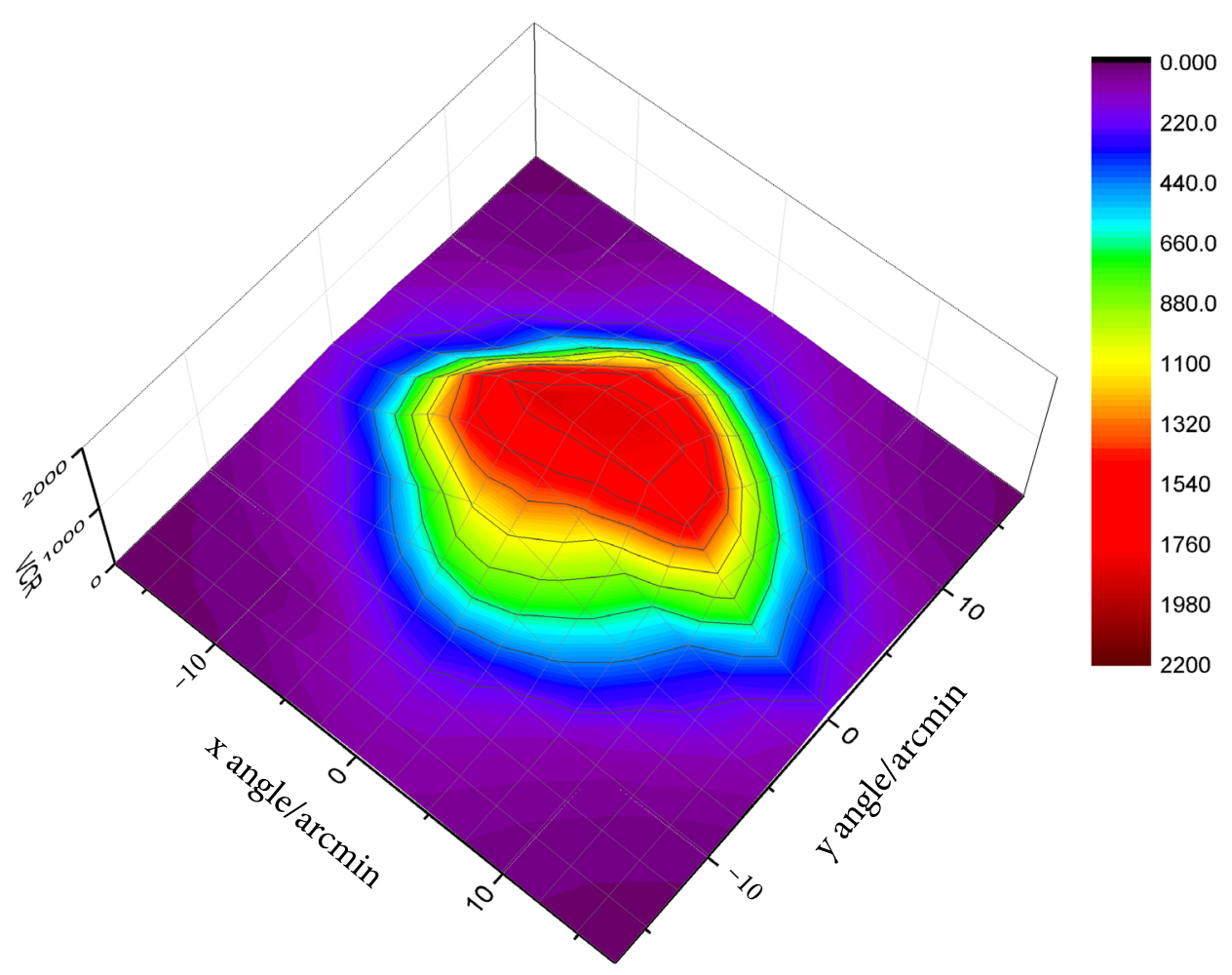

Fig. 6. Contrast ratio dependence on the angular deviation when external electrical field is applied. Crystal No. 1.

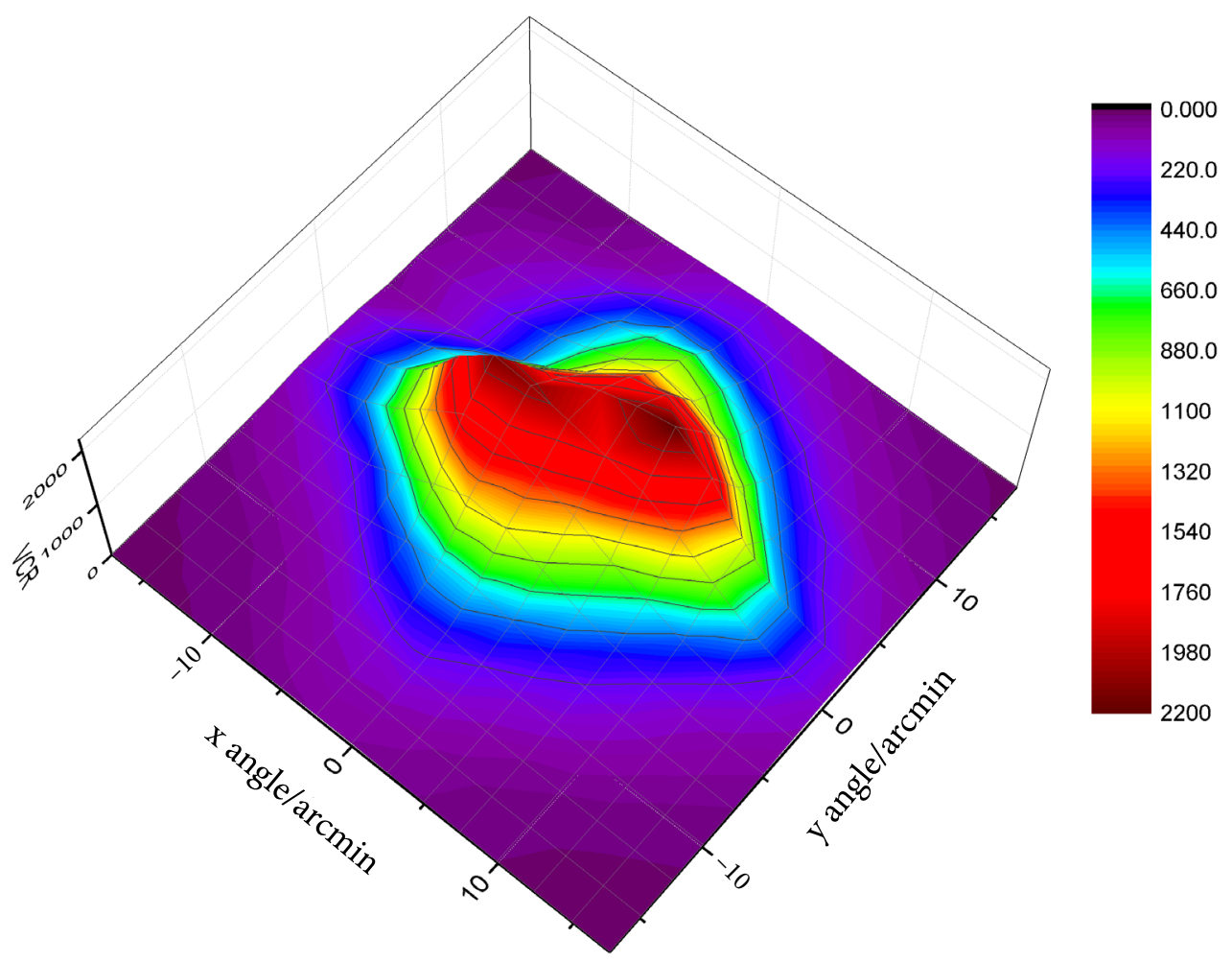

Fig. 7. Contrast ratio dependence on the angular deviation when external electrical field is applied. Crystal No. 2. 
a deformed circle form. The investigation results show that the contrast ratio when the external electrical field is applied decreases more than two times when the angular deviation of the crystal optical axis from the centre of the crystal is more than $5 \mathrm{arcmin}$.

\section{Impact of optical axis angular deviation on the contrast ratio of the two optically aligned crystals}

The Pockels cell based on the BBO crystals has to be affected by the strong external electrical field in order to rotate the beam polarizations. The voltage required for $90^{\circ}$ rotation of the polarised light is called the half-wave voltage. The half-wave voltage for Pockels cells based on BBO crystals is defined by the equation $[3,12,16$

$$
U_{\lambda / 2}=\frac{\lambda d}{2 r_{i j} n_{\mathrm{o}}^{3} l}
$$

where $U_{\lambda / 2}$ is the half-wave voltage, $n_{\mathrm{o}}$ is the ordinary index of refraction of the crystal, $r_{i j}$ is the electrooptic constant, $\lambda$ is the wavelength of the light, $d$ is the distance between crystal electrodes, and $l$ is the length of the crystal.
It is seen (Eq. 1) that the half-wave voltage decreases if the length of the crystal increases. It is expensive to grow long high-quality crystals, therefore, multiple optically aligned crystals of the same dimensions for decreasing of the half-wave voltage can be used. However, the optical axis of crystals has to be aligned with precision.

The double Pockels cell based on optically aligned $\mathrm{BBO}$ crystals was investigated. Additionally, the single $\mathrm{BBO}$ Pockels cell was investigated to compare the differences in the results in comparison with the cell based on the two optically aligned crystals. The dependence of the contrast ratio on the angular deviation when no external electrical field is applied to the cells was measured. The measurement results for the case of two crystals are given in Fig. 8, while for the case of the single crystal they are in Figs. 3 and 4. It is seen that the contrast ratio of the double Pockels cell based on optically aligned $\mathrm{BBO}$ crystals is by $30 \%$ lower as compared to the case when the single crystal was used. This could happen because the total depolarization introduced by two crystals is higher than depolarization of a single crystal.

The contrast ratio dependence on the crystal optical axis angular deviation when the external

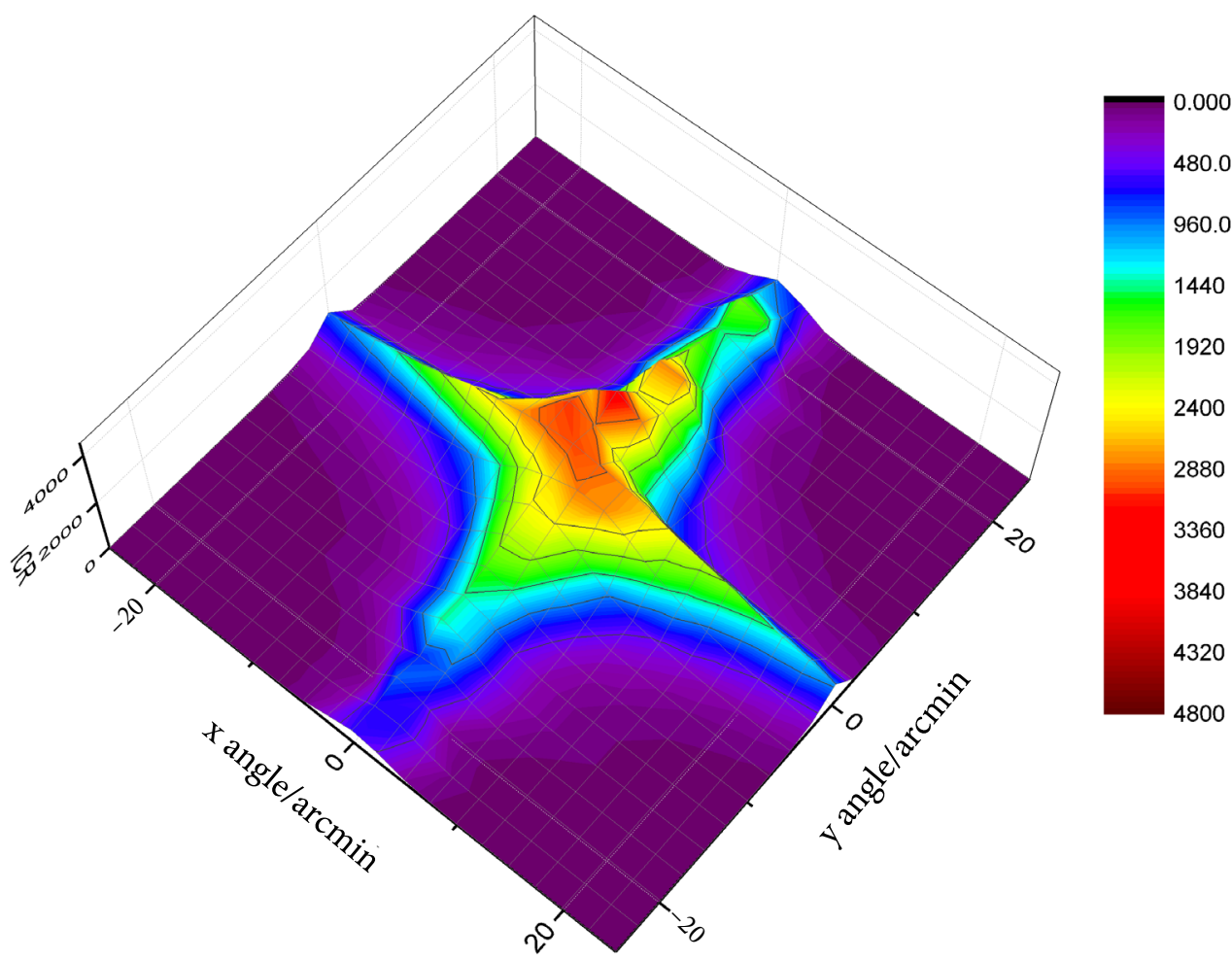

Fig. 8. Contrast ratio dependence on the angular deviation when no external electrical field is applied. Two optically aligned crystals. 
electrical field is applied to the double Pockels cell based on optically aligned BBO crystals was measured (Fig. 9). It is seen that there are two zones where the contrast ratio of Pockels cell crystals reaches more than 1100 . This happened because the external electrical field strength was selected incorrectly. In order to prove such a statement, the electrical field strength was reduced (voltage between crystal electrodes was reduced from 4.45 to $4.3 \mathrm{kV}$ ). The investigation results show (Fig. 10) that when the electrical field strength is decreased, two zones, where higher contrast ratio values are detected, move away from the centre of the optical axis.

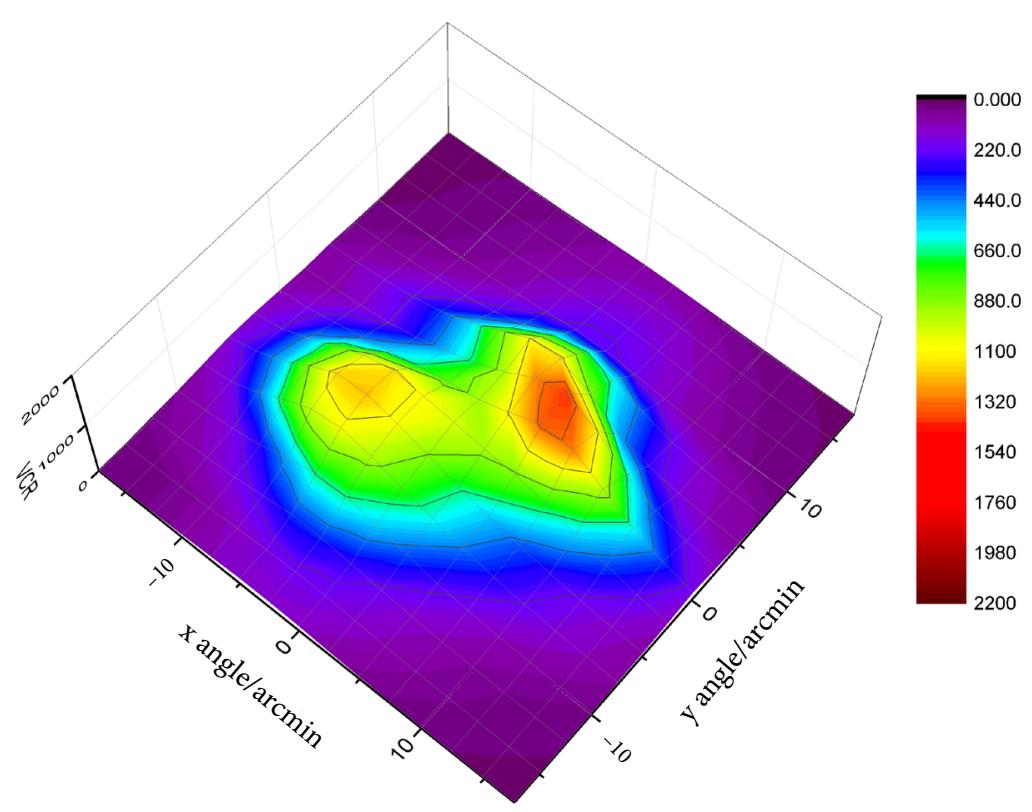

Fig. 9. Contrast ratio dependence on the angular deviation when external electrical field is applied ( $4.45 \mathrm{kV}$ between electrodes). Two optically aligned crystals.

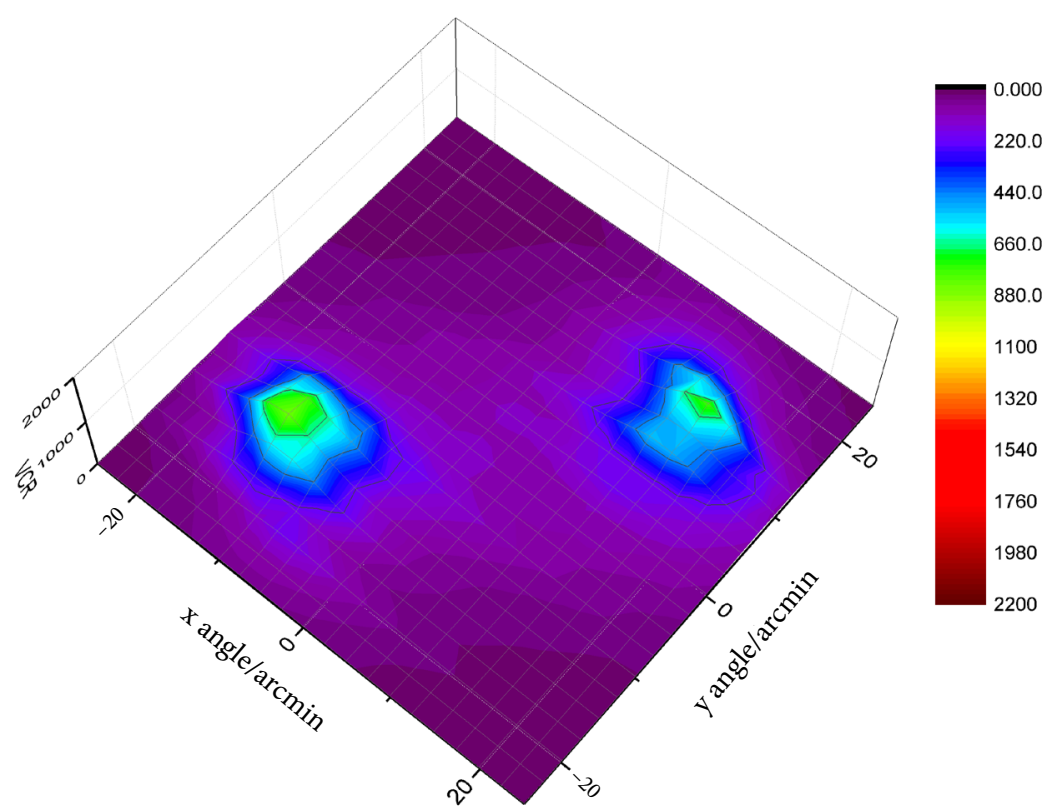

Fig. 10. Contrast ratio dependence on the angular deviation when external electrical field is applied ( $4.3 \mathrm{kV}$ between electrodes). Two optically aligned crystals. 


\section{Conclusions}

1. The contrast ratio of the Pockels cell based on the $\mathrm{BBO}$ crystals decreases more than two times when the angular deviation from the centre of the crystal optical axis is more than 5 arcmin.

2. There are two positions where the contrast ratio reaches maximal values in the case when the strength of the external electric field applied to the Pockels cell crystal is incorrect.

3. The contrast ratio of the Pockels cell can be higher with the applied external field than with no external field applied if the crystal is aligned incorrectly.

4. Two optically aligned crystals of the same dimensions can be used for reducing the half-wave voltage, however, the contrast ratio of the Pockels cell based on the two optically aligned BBO crystals is by $30 \%$ lower as compared to the case when the single crystal is used.

\section{References}

[1] R.R. Gattass, L.R. Cerami, and E. Mazur, Micromachining of bulk glass with bursts of femtosecond laser pulses at variable repetition rates, Opt. Express 14(12), 5279-5284 (2006), https:// doi.org/10.1364/OE.14.005279

[2] H. Fattahi, A. Alismail, H. Wang, J. Brons, O. Pronin, T. Buberl, L. Vámos, G. Arisholm, A. Azzeer, and F. Krausz, High-power, 1-ps, all-Yb:YAG thin-disk regenerative amplifier, Opt. Lett. 41, 1126-1129 (2016), https://doi. org/10.1364/OL.41.001126

[3] M. Roth, M. Tseitlin, and N. Angert, Oxide crystals for electro-optic Q-switching of lasers, Glass Phys. Chem. 31(1), 86-95 (2005), https://doi. org/10.1007/s10720-005-0028-6

[4] G. Sinkevičius and A. Baškys, Pjezoelektrinių virpesių Pokelso narvelio kalio dideuterio fosfato ir beta bario borato kristaluose tyrimas / Investigation of piezoelectric ringing in the Pockels cells based on the DKDP and BBO crystal, Moksl. Liet. Ateitis / Sci. Future Lith. 10, 1-4 (2018), https://doi.org/10.3846 mla.2018.2485 [in Lithuanian].

[5] G. Sinkevicius and A. Baskys, in: Proceedings of the 2017 Open Conference of Electrical, Electronic and Information Sciences (eStream) (IEEE, Vilnius, 2017) pp. 1-4, https://doi.org/10.1109 eStream.2017.7950307

[6] F. Bergmann, M. Siebold, M. Loeser, F. Röser, D. Albach, and U. Schramm, MHz repetition rate of $\mathrm{Yb}: \mathrm{YAG}$ and $\mathrm{Yb}: \mathrm{CaF}_{2}$ regenerative picosecond laser amplifiers with a BBO pockels cell, Appl. Sci. 5(4), 761-769 (2015), https://doi.org/10.3390/ app5040761

[7] G. Sinkevicius and A. Baskys, Investigation of piezoelectric ringing frequency response of beta barium borate crystals, Crystals 9(1), 1-10 (2019), https://doi.org/10.3390/cryst9010049

[8] W. Koechner, Solid-State Laser Engineering (Springer, New York, 2006), https://doi. org/10.1007/0-387-29338-8

[9] F.-S. Chen, Modulators for optical communications, Proc. IEEE 58(10), 1440-1457 (1970), https://doi.org/10.1109/PROC.1970.7970

[10]G. Sinkevicius, A. Baskys, and N. Paulauskas, Influence of the piezoelectric ringing on the temperature of the beta barium borate crystal, Acta Phys. Pol. A 134(2), 535-538 (2018), https://doi. org/10.12693/APhysPolA.134.535

[11]H. Jelínková, J. Šulc, P. Koranda, M. Němec, M. Čech, M. Jelínek, and V. Škoda, $\mathrm{LiNbO}_{3}$ Pockels cell for Q-switch of Er:YAG laser, Laser Phys. Lett. 1(2), 59-64 (2004), https://doi. org/10.1117/12.525990

[12]Z. Bai, Z. Bai, Z. Kang, F. Lian, W. Lin, and Z. Fan, Non-pulse-leakage $100-\mathrm{kHz}$ level, high beam quality industrial grade $\mathrm{Nd}: \mathrm{YVO}_{4}$ picosecond amplifier, Appl. Sci. 7(6), 1-8 (2017), https://doi. org/10.3390/app7060615

[13]M. Abarkan, J. Salvestrini, M. Aillerie, and M. Fontana, Frequency dispersion of electrooptical properties over a wide range by means of time-response analysis, Appl. Opt. 42, 2346-2353 (2003), https://doi.org/10.1364/AO.42.002346

[14] T.M. Jeong, T.J. Yu, S.K. Lee, J.H. Sung, C.H. Nam, and J. Lee, in: Proceedings of the 2013 Conference on Lasers and Electro-Optics/Pacific Rim (Optical Society of America, Kyoto, 2013) pp. 1-2, https:// doi.org/10.1364/OE.20.010807

[15]Y.F. Ma, X. Yu, X.D. Li, C. Wang, R.P. Yan, and J.H. Yu, in: Proceedings of the 2013 Conference on 
Lasers Electro-Optics Europe and International Quantum Electronics Conference (IEEE, Munich, 2013) pp. 1-1, https://doi.org/10.1109/CLEOEIQEC.2013.6800652

[16]D. Nickel, C. Stolzenburg, A. Beyertt, A. Giesen, J. Häußermann, F. Butze, and M. Leitner, in: Advanced Solid-State Photonics, Technical Digest (Optical Society of America, Vienna, 2005) pp. 33111-33117, https://doi. org/10.1063/1.1867052

\title{
POKELSO NARVELIŲ SU BETA BARIO BORATO KRISTALU KONTRASTO PRIKLAUSOMYBĖS NUOO LAZERIO SPINDULIO IR OPTINĖS AŠIES KRYPČIŲ NESUTAPIMO TYRIMAS
}

\author{
G. Sinkevičius a, ${ }^{a,}$ A. Baškys a,b \\ ${ }^{a}$ Fiziniu ir technologijos mokslu centras, Vilnius, Lietuva \\ ${ }^{\mathrm{b}}$ Gedimino technikos universiteto Elektronikos fakultetas, Vilnius, Lietuva
}

\section{Santrauka}

Atliktas Pokelso narvelio su beta bario borato kristalu kontrasto priklausomybès nuo optinès ašies nuokrypio kampo tyrimas 2 arcmin 28 arcsec geba, 49 arcmin 34 arcsec diapazone. Taip pat atlikta Pokelso narvelio su vienu kristalu ir su dviem optiškai išstatytais krista-

lais lyginamoji kontrasto priklausomybės nuo nuokrypio kampo analizè. Tyrimų rezultatus galima pritaikyti skaičiuojant lazerio spindulio fokusą siekiant užtikrinti aukštą Pokelso narvelio kontrastą didelés galios lazerių sistemose. 